九州大学学術情報リポジトリ

Kyushu University Institutional Repository

\title{
Occurrence of Ploidy Variation in Camellia Xvernalis
}

Tateishi, Nobumine

Graduate School of Bioresource and Bioenvironmental Sciences, Kyushu University

Ozaki, Yukio

Faculty of Agriculture, Kyushu University

Okubo, Hiroshi

Faculty of Agriculture, Kyushu University

https://doi.org/10.5109/9273

出版情報：九州大学大学院農学研究院紀要. 52 (1)，pp.11-15，2007-02-28. Faculty of Agriculture， Kyushu University

バージョン :

権利関係 : 


\title{
Occurrence of Ploidy Variation in Camellia $\times$ vernalis
}

\section{Nobumine TATEISHI ${ }^{1 *}$, Yukio OZAKI ${ }^{2}$ and Hiroshi OKUBO}

\author{
Laboratory of Horticultural Science, Division of Agricultural Botany, \\ Department of Plant Resources, Faculty of Agriculture, \\ Kyushu University, Fukuoka 812-8581, Japan \\ (Received November 2, 2006 and accepted December 1, 2006)
}

\begin{abstract}
Maternal inheritance of chloroplast DNA (cpDNA) in the genus Camellia was confirmed using the polymorphism of $a t p \mathrm{H}-a t p$ I region. CpDNAs of all $C . \times$ vernalis cultivars showed the same type as those of C. sasanqua, and all the progenies from C.× vernalis, either open pollinated or crossed, had the same cpDNA type as their maternal plants. Flow cytometry subjected to estimate the ploidy level of $C$. japonica, $C$. sasanqua and $C . \times$ vernalis revealed that there is a very strong positive linear correlation $\left(r^{2}=0.981\right)$ between fluorescent intensity and ploidy level, suggesting that the method is useful to investigate the ploidy level in Camellia. Natural occurrence of ploidy variation was shown in the progenies of tetraploid C.× vernalis cultivars, and zygote patterns of the progenies are discussed.
\end{abstract}

\section{INTRODUCTION}

Camellia $\times$ vernalis is considered to be a hybrid species between $C$. sasanqua $(2 \mathrm{n}=6 \mathrm{x}=90)$ and $C$. japonica $(2 \mathrm{n}=2 \mathrm{x}=30)$ (Tanaka et al., 1986). It has excellent characters like a long bloom time, a large number of flowers and large variations of flower colors and shapes. Tanaka et al. (1986) classified C.× vernalis cultivars into four groups; eleven cultivars of the 'Gaisen' type tetraploid, thirty-five of the triploid, seven of the 'Egao' type tetraploid and seven of the pentaploid groups, and postulated the origin of each group as follows; 1 ) the 'Gaisen' type tetraploids $(2 \mathrm{n}=$ $4 \mathrm{x}=60$ ) were resulted from the primary hybrid between C. sasanqua and C. japonica, 2) the triploid $(2 \mathrm{n}=3 \mathrm{x}=$ $45)$ and pentaploid $(2 n=5 x=75)$ groups originated

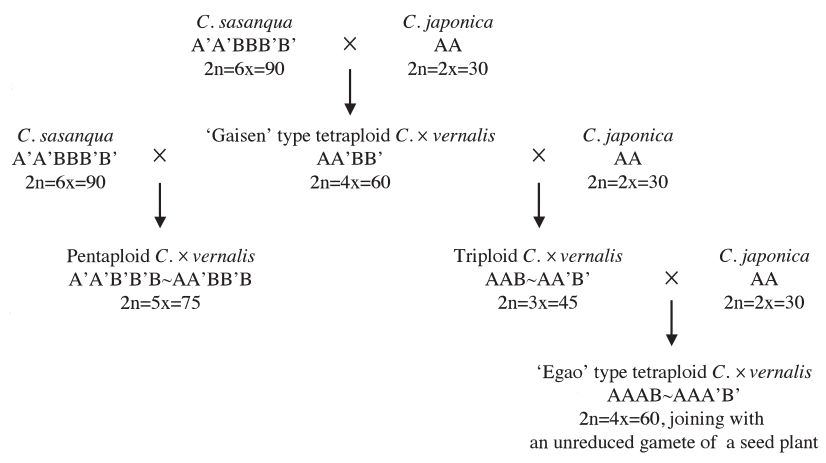

Fig. 1. Outline of introgressive hybrid formation between $C$. sasanqua and C. japonica (Tanaka, 1985, modified by N. T.).

\footnotetext{
1 Laboratory of Horticultural Science, Division of Agricultural Botany, Department of Plant Resources, Graduate School of Bioresource and Bioenvironmental Sciences, Kyushu University, Fukuoka 812-8581, Japan

${ }^{2}$ Laboratory of Agricultural Ecology, Division of Agricultural Ecology, Department of Plant Resources, Faculty of Agriculture, Kyushu University, Fukuoka 811-2307, Japan

* Corresponding author (E-mail: tateishi@agr.kyushu-u.ac.jp)
}

from the backcross generations of a tetraploid 'Gaisen' type with $C$. japonica and $C$. sasanqua, respectively and 3 ) the 'Egao' type tetraploids $(2 \mathrm{n}=4 \mathrm{x}=60)$ were derived from the second backcross generation between an unreduced triploid gamete of the triploid $C . \times$ vernalis and a normal haploid gamete of $C$. japonica (Fig. 1).

Polymorphism of chloroplast DNA (cpDNA) has been often adopted in phylogenic study because cpDNA shows maternal inheritance (Corriveau and Coleman, 1988) and slower evolution speed than nuclear DNA (Small et al., 1998). Shibata et al. (2000) investigated the polymorphism of $a t p \mathrm{H}-a t p \mathrm{I}$ region of cpDNA in the genus Camellia, and reported two types of PCR products (types A and B for approx. $800 \mathrm{bp}$ and 1,200 bp, respectively). They also reported that $C$. sasanqua, $C$. japonica ssp. rusticana and $C$. chrysantha were classified into type A and $C$. japonica and $C$. sinensis were into type $\mathrm{B}$, suggesting that the polymorphism can be used as a genetic marker to distinguish the species among genus Camellia. Tanaka et al. (2005) revealed that the products of this region in some $C . \times$ vernalis cultivars were type A, demonstrating that $C$. sasanqua was a maternal ancestor of $C . \times$ vernalis.

Ploidy levels have been determined by counting the somatic chromosomes, and also been estimated by measuring the length of stomata in many plant species. The procedures are still difficult and/or time consuming in Camellia, particularly in high ploidy species, so that the efficient analytical methods for rapid and suitable determination of ploidy levels have been long desired. Recently, flow cytometry has become a useful tool for rapid and efficient estimation of genome size and ploidy levels in some crops (Eaton et al., 2004; Hcini et al., 2006).

We investigated atpH-atpI region in $C . \times$ vernalis cultivars, their open pollinated seedlings and artificially crossed progenies with $C$. japonica to confirm their maternal inheritance, and examined their ploidy variation by flow cytometric analysis. 


\section{MATERIALS AND METHODS}

\section{Chloroplast DNA analysis}

Plant materials

Seven cultivars including four diploids ('Hatsu-arashi', 'Kanto-hatsuwarai', 'Kariginu' and 'Shiratama') and three triploids ('Akashigata', 'Akebono' and 'Kumagai') of C. japonica, two cultivars ('Choji-guruma' and 'Inu-hariko') and four accessions of C. sasanqua from Kurokamiyama, Saga Pref., Hirado, Nagasaki Pref., Funakakushi, Goto Is., Nagasaki Pref. and Osuzuyama, Miyazaki Pref., and eight cultivars ('Egao', 'Gaisen', 'Omi-goromo', 'Sado', 'Sayo-hime', 'Takarazuka', 'Tamuke-yama' and 'Ume-ga-ka') of C.x vernalis were supplied to investigate their cpDNA. Twenty-one plants obtained from the crosses between 'Gaisen' and C. japonica, and between 'Ume-ga-ka' and C. japonica, and the seedlings from the open pollination of 'Gaisen' and 'Ume-ga-ka' were also used.

\section{DNA extraction}

Total genomic DNA was extracted from $100 \mathrm{mg}$ of frozen young leaf or leaf/flower buds by the modified CTAB method (Kobayashi et al., 1998). Frozen samples were powdered with a mortar and a pestle, and washed three times with $1 \mathrm{ml}$ of $50 \mathrm{mM}$ Tris-HCl buffer ( $\mathrm{pH}$ 8.0) containing $5 \mathrm{mM}$ of EDTA, $350 \mathrm{mM}$ of sorbitol, $0.1 \%$ of mercaptoethanol and 10\% polyethylene-glycol 6,000. The pellet was suspended in $500 \mu \mathrm{l}$ of CTAB buffer and separated with chloroform-isoamyl alcohol (24:1). After centrifugation at $12,000 \mathrm{rpm}$ for $5 \mathrm{~min}$ at room temperature, the aqueous layer was transferred into $1.5 \mathrm{ml}$ micro tubes. The DNA precipitated by isopropanol was washed with $70 \%$ ethanol and dried. The DNA was, then, dissolved in Tris-EDTA buffer.

\section{PCR analysis}

Atp $\mathrm{H}-a t p \mathrm{I}$ region was amplified by PCR by using a pair of primers, atpH (5'-TTGACCAACTCCAGGTCCAA-3') and atpI (5'-CCGCAGCTTATATAGGCGAA-3'). PCR amplification was performed in a total volume of $25 \mu \mathrm{l}$ solution containing $25 \mathrm{ng}$ template DNA, $0.5 \mu \mathrm{M}$ of each primer, $1.25 \mathrm{mM}$ of each dNTP, $2.5 \mu \mathrm{l}$ of $10 \times$ reaction buffer and 0.5 unit of Taq DNA polymerase (Roche). The amplification was carried out by using Program Temp Control System PC-701 (ASTEC) with one cycle of $30 \mathrm{sec}$ at $94^{\circ} \mathrm{C}$, followed by 45 cycles of 30 sec at $94^{\circ} \mathrm{C}, 2 \mathrm{~min}$ at $60^{\circ} \mathrm{C}$ and $3 \mathrm{~min}$ at $72^{\circ} \mathrm{C}$ and one cycle of $7 \mathrm{~min}$ at $72^{\circ} \mathrm{C}$. The PCR products were separated by electrophoresis in 1.5\% agarose gel, and visualized under UV illumination after staining with ethidium bromide.

\section{Flow cytometric analysis \\ Plant materials}

Five cultivars including four diploids ('Hatsu-arashi', 'Kanto-hatsuwarai', 'Kariginu' and 'Shiratama') and one triploid ('Akebono') of C. japonica, two accessions of $C$. sasanqua from Hirado, Nagasaki Pref. and Harumaki, Yakushima Is., Kagoshima Pref., and seven cultivars
('Egao', 'Omi-goromo', 'Sado', 'Sayo-hime', 'Takarazuka', 'Tamuke-yama' and 'Ume-ga-ka') of C.× vernalis were screened for flow cytometry analysis. Twenty-five plants (14 triploids, one pentaploid, one hexaploid and nine unknown) obtained from the crosses between 'Gaisen' and C. japonica and between 'Ume-ga-ka' and C. japonica, and the seedlings of the open pollination of 'Gaisen' and 'Ume-ga-ka' were also provided for the analysis.

\section{Flow cytometry}

Approximately $1 \mathrm{~cm}^{2}$ petal was chopped with a sharp razor blade in nuclei extraction buffer (High resolution DNA kit, Partec), and the suspension containing the released nuclei was passed through a $50 \mu \mathrm{m}$ nylon mesh filter. Then the nuclei in filtrate were stained with four times volumes of staining solution (High resolution DNA kit, Partec) containing 4'-6-diamidino-2-phenylindole (DAPI). After shaking the solution gently, samples were analyzed with a flow cytometer (PA Ploidy Analyzer, Partec). Relative DNA content was estimated according to the fluorescent intensity of the prominent peak in each measurement. Correlation between fluorescent intensity of the prominent peak and ploidy level was evaluated and statistical analysis of the intensity of each cultivar/accession was carried out by Tukey 's HSD test.

\section{RESULTS AND DISCCUSION}

\section{Chloroplast DNA analysis}

Two types of PCR amplified products were observed in $a t p \mathrm{H}-a t p \mathrm{I}$ region; types $\mathrm{A}$ (approx. $800 \mathrm{bp}$ ) and $\mathrm{B}$ (approx. 1,200 bp) (Fig. 2), corresponding with the previous studies (Shibata et al., 2000; Tanaka et al., 2005). 'Egao', 'Gaisen', 'Sayo-hime', 'Takarazuka' and 'Ume-ga-ka' of C.× vernalis had A type cpDNA in accordance with Tanaka (2005)'s result (Table 1). Other C.× vernalis cultivars, 'Omi-goromo', 'Sado' and 'Tamuke-yama' also had A type cpDNA suggesting that their maternal ancestors were also C. sasanqua. All the artificially crossed progenies and open pollinated seedlings showed the same cpDNA type (Type A) as

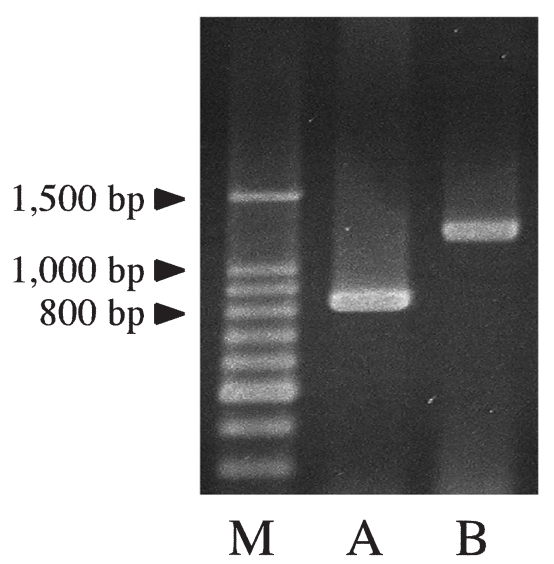

Fig. 2. Profiles of PCR products of $a t p H-a t p I$ region in cpDNA. A: C. sasanqua (approx. $800 \mathrm{bp}$ ) B: C. japonica (approx. 1,200 bp) M: 100 bp DNA ladder marker. 
Table 1. PCR products type of atpH-atpI region of cpDNA in C. japonica, C. sasanqua, C.x vernalis and their progenies

\begin{tabular}{|c|c|c|}
\hline & Cultivar, accession & atp $\mathrm{H}-a t p \mathrm{I}$ \\
\hline \multirow[t]{7}{*}{ C. japonica } & 'Hatsu-arashi' & $\mathrm{B}$ \\
\hline & 'Kanto-hatsuwarai' & $\mathrm{B}$ \\
\hline & 'Kariginu' & $\mathrm{B}$ \\
\hline & 'Shiratama' & $\mathrm{B}$ \\
\hline & 'Akashigata' & $\mathrm{B}$ \\
\hline & 'Akebono' & $\mathrm{B}$ \\
\hline & 'Kumagai' & $\mathrm{B}$ \\
\hline \multirow[t]{6}{*}{ C. sasanqua } & 'Choji-guruma' & $\mathrm{A}$ \\
\hline & 'Inu-hariko' & A \\
\hline & Kurokamiyama, Saga Pref. & $\mathrm{A}$ \\
\hline & Hirado, Nagasaki Pref. & $\mathrm{A}$ \\
\hline & Funakakushi, Goto Is., Nagasaki Pref. & $\mathrm{A}$ \\
\hline & Osuzuyama, Miyazaki Pref. & $\mathrm{A}$ \\
\hline \multirow[t]{8}{*}{ C. $\times$ vernalis } & 'Egao' & $\mathrm{A}$ \\
\hline & ‘Gaisen’ & $\mathrm{A}$ \\
\hline & 'Omi-goromo' & $\mathrm{A}$ \\
\hline & 'Sado' & $\mathrm{A}$ \\
\hline & 'Sayo-hime' & $\mathrm{A}$ \\
\hline & 'Takarazuka' & $\mathrm{A}$ \\
\hline & 'Tamuke-yama' & $\mathrm{A}$ \\
\hline & 'Ume-ga-ka' & $\mathrm{A}$ \\
\hline \multirow[t]{12}{*}{ Crosses } & C. $\times$ vernalis 'Gaisen' $\times$ C. japonica No. 2 & $\mathrm{~A}$ \\
\hline & C.x vernalis 'Gaisen' $\times$ C. japonica No. 3 & $\mathrm{~A}$ \\
\hline & C. $\times$ vernalis 'Gaisen' $\times$ C. japonica No. 4 & $\mathrm{~A}$ \\
\hline & C. $\times$ vernalis 'Gaisen' $\times$ C. japonica No. 5 & $\mathrm{~A}$ \\
\hline & C.× vernalis 'Gaisen' $\times$ C. japonica No. 6 & A \\
\hline & C.× vernalis 'Gaisen' $\times$ C. japonica No. 7 & $\mathrm{~A}$ \\
\hline & C.x vernalis ‘Gaisen' $\times$ C. japonica No. 9 & A \\
\hline & C.× vernalis 'Gaisen' $\times$ C. japonica No. 10 & $\mathrm{~A}$ \\
\hline & C.× vernalis 'Gaisen' $\times$ C. japonica No. 11 & $\mathrm{~A}$ \\
\hline & C.× vernalis 'Gaisen' $\times$ C. japonica No. 12 & $\mathrm{~A}$ \\
\hline & C.× vernalis ‘Gaisen' $\times$ C. japonica No. 13 & $\mathrm{~A}$ \\
\hline & C.× vernalis 'Ume-ga-ka' $\times$ C. japonica No. 1 & A \\
\hline \multirow[t]{9}{*}{ Open pollination } & C.× vernalis 'Gaisen' open seedling No. 1 & A \\
\hline & C.x vernalis 'Gaisen' open seedling No. 3 & $\mathrm{~A}$ \\
\hline & C. $\times$ vernalis 'Gaisen' open seedling No. 5 & A \\
\hline & C.x vernalis 'Gaisen' open seedling No. 7 & $\mathrm{~A}$ \\
\hline & C.x vernalis 'Gaisen' open seedling No. 8 & $\mathrm{~A}$ \\
\hline & C.× vernalis ‘Gaisen' open seedling No. 9 & $\mathrm{~A}$ \\
\hline & C.× vernalis ‘Gaisen’ open seedling No. 10 & A \\
\hline & C.x vernalis 'Ume-ga-ka' open seedling No. 1 & $\mathrm{~A}$ \\
\hline & C.x vernalis 'Ume-ga-ka' open seedling No. 2 & $\mathrm{~A}$ \\
\hline
\end{tabular}

their maternal parents, confirming the maternal inheritance of cpDNA in Camellia.

\section{Flow cytometric analysis}

When the fluorescent intensity of the prominent peak of C. sasanqua (hexaploid) was adjusted to 400, the values of diploids, triploids, tetraploids and pentaploids were around 140, 200, 270 and 350, respectively (Fig. 3). Significant differences $(P<0.05)$ of the fluorescent intensities were found between different ploidy cultivars/accessions. The strong positive linear correlation $\left(r^{2}=0.981\right)$ between chromosome number and fluorescent intensity was recognized (Fig. 4). These results suggest that flow cytometry is useful for distinguishing ploidy levels in the genus Camellia. Ploidy levels of the accessions whose chromosome number were unknown were estimated from the results of statistical analysis (Fig. 3). It was suggested that, for example, C.× vernalis 'Sado' and 'Gaisen' open seedling No. 9 were triploid and tetraploid, respectively. Pentaploidy was estimated in 'Gaisen' open seedlings Nos. 2, 7, 5, 1 and 4. 'Gaisen' open seedlings Nos. 6 and 3 and 'Ume-ga-ka' open seedling No. 1 were considered to be aneuploids.

Ploidy variation was recognized in open pollinated progenies from 'Gaisen' and 'Ume-ga-ka'. The triploid progeny ('Gaisen' open seedling No. 10) might be derived from the cross between 'Gaisen' and C. japon$i c a$, and the tetraploid progeny ('Gaisen' open seedling No. 9) might be from the cross with other tetraploids of C.x vernalis. The following two possibilities are considered for the pentaploid progenies ('Gaisen' open seedlings Nos. 8, 2, 7, 5, 1 and 4); 1) progenies from the zygote between an unreduced tetraploid gamete of 'Gaisen' and normal haploid gamete of C. japonica or 2) progenies from the zygote between normal diploid gamete of 'Gaisen' and normal triploid gamete of $C$. sasanqua. The former hypothesis seems unlikely because all the progenies of 'Gaisen'× C. japonica were 


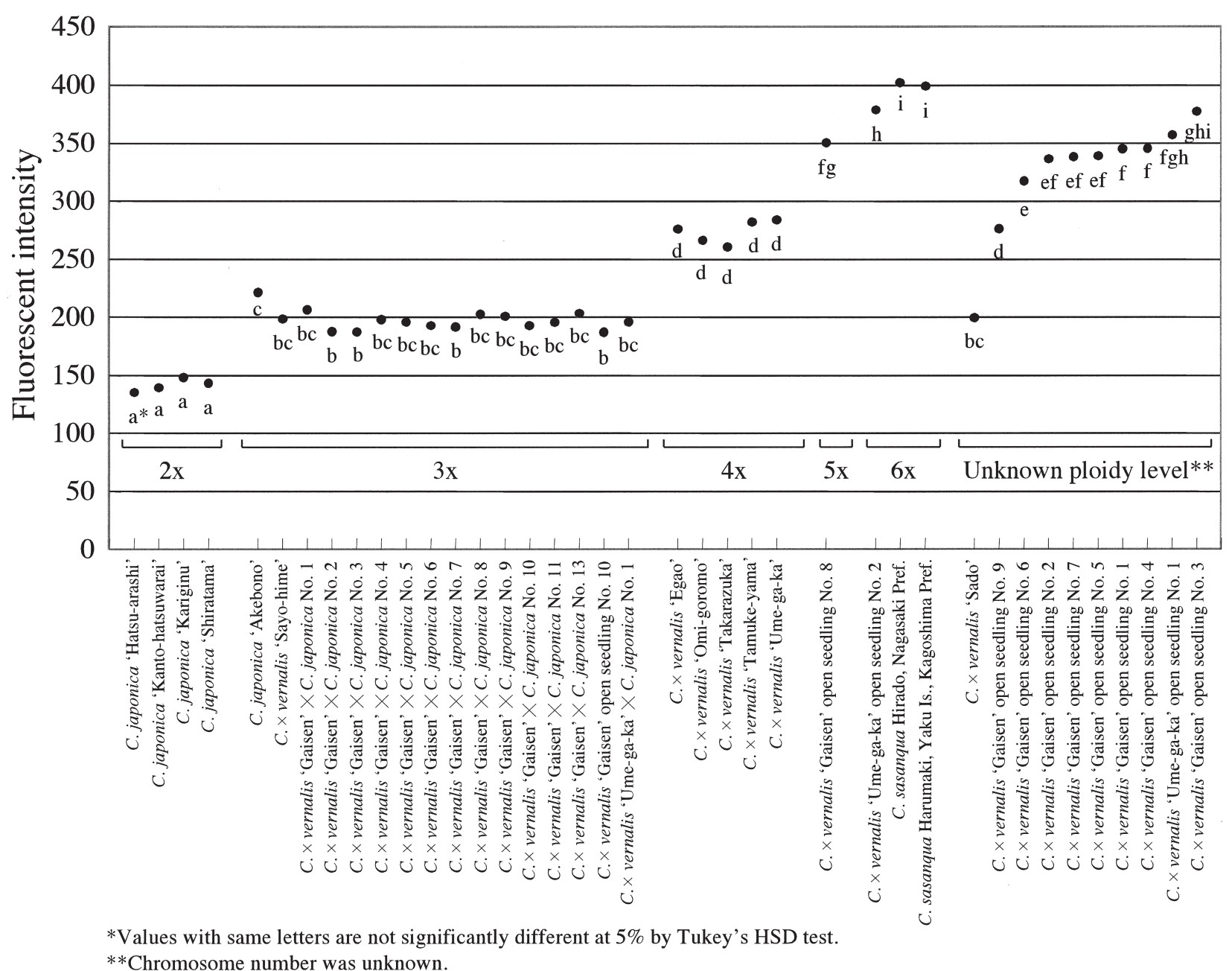

Fig. 3. Fluorescent intensity of the prominent peak in C. japonica, C. sasanqua, C.x vernalis and their progenies.

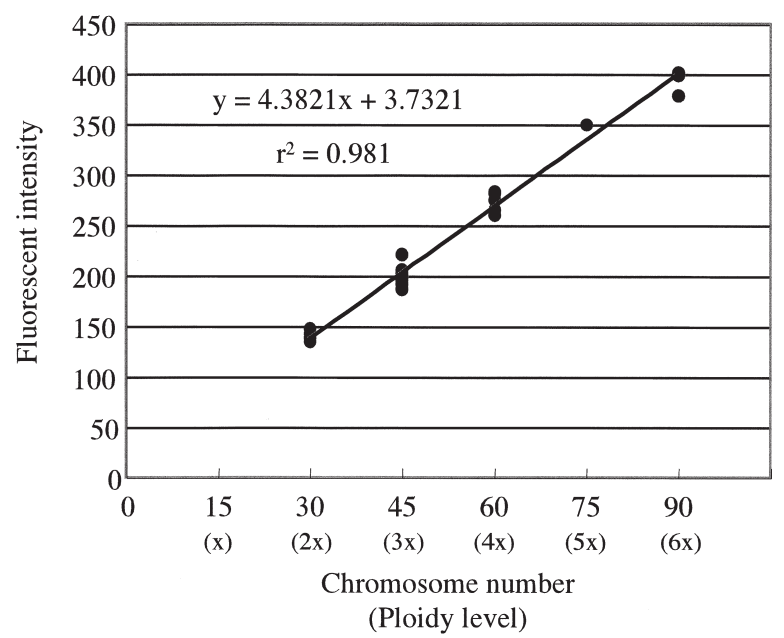

Fig. 4. Correlation between chromosome number and fluorescent intensity in Camellia species.

triploids. Hexaploid progeny ('Ume-ga-ka' open seedling No. 2) might be derived from a zygote between an unreduced tetraploid gamete and normal diploid gamete of tetraploid $C . \times$ vernalis. It is impossible to explain the mechanism of the appearance of aneuploids in this study. The ploidy variation in the progenies of 'Gaisen' and 'Ume-ga-ka' might be established by natural crossing, contributing to a ploidy variation of $C . \times$ vernalis.

A significant difference $(\mathrm{P}<0.05)$ of fluorescent intensities was found between triploid $C$. japonica 'Akebono' and some triploid C.× vernalis progenies, 'Gaisen'× C. japonica Nos. 2, 3 and 7 and 'Gaisen' open seedling No. 10. The three times value of fluorescent intensity of diploid C. japonica and two times value of that of triploid C. japonica were approximately 420 and 440 , respectively. Although these values are theoretically to be equal to that of hexaploid, the values of actual hexaploid C. sasanqua were approximately 400. Tanaka (1985) inferred from Kondo (1975, 1978)'s observation that the genome structure of $C$. japonica, C. sasanqua and 'Gaisen' type $C . \times$ vernalis were AA, A'A'BBB'B' and AA'BB', respectively. The genome structure of triploid C. japonica 'Akebono', triploid C.× vernalis and 'Egao' type tetraploid $C . \times$ vernalis are thought to be AAA, $\mathrm{AA}^{()} \mathrm{B}^{()}$and $\mathrm{AAA}^{()} \mathrm{B}^{()}$, respectively from Tanaka's supposition. It was, therefore, suggested that DNA contents of genomes A and B are different. The fluorescent intensity of single A genome was estimated to be 70-75 and that of B genome 55-60. The fluorescent intensity of 'Egao' type tetraploid C.× 
vernalis $\left(\mathrm{AAA}^{()} \mathrm{B}^{()}\right)$and hexaploid $C$. sasanqua (A'A'BBB'B') was calculated to be 285 and 390 in maximum, respectively, based on our estimation, and the values are both in accordance with those of the actual fluorescent intensity of them.

\section{Conclusion}

We confirmed the maternal inheritance of cpDNA in Camellia using the polymorphism of $a t p \mathrm{H}-a t p \mathrm{I}$ region in some $C . \times$ vernalis cultivars, their open pollinated seedlings and artificially crossed progenies with $C$. japonica. Our study also demonstrated that flow cytometry makes rapid and efficient determination of ploidy levels possible in Camellia and gave some hypotheses to the mechanism causing ploidy variation in the progenies of $C . \times$ vernalis.

\section{ACKNOWLEDGMENTS}

The authors wish to thank Associate Professor Koichiro Gyokusen in the Laboratory of Silviculture, Faculty of Agriculture, Kyushu University for cooperation and technical advice in flow cytometric analysis. We are also grateful to Professor Takayuki Tanaka in the Laboratory of Vegetable and Ornamental Horticulture, School of Agriculture, Kyushu Tokai University who had produced some plant materials used in this study.

\section{REFERENCES}

Corriveau, J. L. and A. W. Coleman 1988 Rapid screening method to detect potential biparental inheritance of plastid DNA and results for over 200 angiosperm species. Amer. J. Bot., 75: 1443-1458
Eaton, T. D., J. Curley, R. C. Williamson and G. Jung 2004 Determination of the level of variation in polyploidy among kentucky bluegrass cultivars by means of flow cytometry. Crop Sci., 44: 2168-2174

Hcini, K., D. J. Walker, S. Bouzid, E. Gonzalez, N. Frayssinet and E. Correal 2006 Determination of ploidy level and nuclear DNA content in Tunisian populations of Atriplex halimus L. Genet. Resour. Crop Evol., 53: 1-5

Kobayashi, N., T. Horikoshi, H. Katsuyama, T. Handa and K. Takayanagi 1998 A simple and efficient DNA extraction method from the plants, especially from woody plants. Plant Tissue Cult. Biotech., 4: 76-80

Kondo, K. 1975 Cytological studies in cultivated species of Camellia. Thesis of the Doctor Degree, N. Carolina Univ., Chapel Hill, USA

Kondo, K. 1978 Cytological studies in cultivated species of Camellia. III. Tetraploid species and hybrids between diploid species and hexaploid species. Japan. J. Breed., 28: 197-204

Shibata, M., Z. Wang, T. Motegi, S. Kishimoto and R. Aida 2000 PCR-RFLP analysis of chloroplast DNA genes in Camellia 2. Analysis of $a t p \mathrm{H}$ gene region. J. Japan. Soc. Hort. Sci., 69 (suppl. 2): 420

Small, R. L., J. A. Ryburn, R. C. Cronn, T. Seelanan and J. F. Wendel 1998 The tortoise and the hare: choosing between noncoding plastome and nuclear $A D H$ sequences for phylogeny reconstruction in a recently diverged plant group. Amer. J. Bot., 85: 1301-1315

Tanaka T. 1985 Studies on the origin of Camellia vernalis. Thesis of the Doctor Degree, Kyushu Univ., Fukuoka, Japan (In Japanese with English summary)

Tanaka T., N. Hakoda and S. Uemoto 1986 Cytogenetic studies on the origin of Camellia vernalis II. Grouping of C. vernalis cultivars by the chromosome numbers and the relationships between them. J. Japan. Soc. Hort. Sci., 55: 207-214

Tanaka T., T. Mizutani, M. Shibata, N. Tanikawa and C. R. Parks 2005 Cytogenetic studies on the origin of Camelliax vernalis. V. Estimation of the seed parent of $C . \times$ vernalis that evolved about 400 years ago by cpDNA analysis. J. Japan. Soc. Hort. Sci., 74: 464-468 